\title{
ACID-BASE BALANCE OF FARM ANIMALS DURING ADAPTATION TO HIGH AIR TEMPERATURE
}

\author{
Lyudmila K. Buslovskaya $^{1^{*}}$, Alexey Yu. Kovtunenko ${ }^{1}$ \\ ${ }^{1 *}$ Belgorod State University, Russia, 308015, Belgorod, Pobedy street, 85, Russia; \\ *Corresponding Author Lyudmila K. Buslovskaya, e-mail: Buslovskaya @ bsu.edu.ru;
}

Received August 2021; Accepted September 2021; Published October 2021;

DOI: https://doi.org/10.31407/ijees11.447

\begin{abstract}
The state of acid-base balance among the calf bulls of red steppe, black-and-white breeds and the chickens of different ages under the conditions of high air temperature was studied. At a temperature of $38{ }^{\circ} \mathrm{C}$, the bulls increased the respiratory rate significantly (by 2.1-2.3 times), the volume of pulmonary ventilation (by 40.6-50.4\%), oxygen consumption by $14.4 \%$ on average, and the release of carbon dioxide (by $31-40 \%$ ). Thus, $\mathrm{pCO}_{2}$ decreased by $0.55-0.65 \mathrm{kPa}(\mathrm{P}<0.01)$, the active reaction of the blood $\left(\mathrm{pH}_{\text {ist. }}\right)$ increased by $0.017-0.018(\mathrm{P}<0.05)$. An alkalous shift of the respiratory character of the subcompensated stage was recorded in blood, which was more pronounced among black-and-white bulls, as they were less adapted to the heat. By the end of the four-hour exposure, the alkalous shift in the acid-base state of the calf blood persisted, but it passed into the compensated stage. At $21^{\circ} \mathrm{C}$ and the humidity of $70 \%$ the balance of acid-base relations was observed among chickens. All parameters characterizing it were within the physiological norm. At $23{ }^{\circ} \mathrm{C}$, respiratory subcompensated alkalosis was found in the blood of threemonth-old pullets. Whereas among the poultry of other ages, the acid-base balance was maintained with the decrease of $\mathrm{pCO}_{2}$ at this temperature. At $25{ }^{\circ} \mathrm{C}$ the chickens of all ages, except for 12-day-old chickens, had compensated respiratory alkalosis in blood. 12-day-old chickens showed metabolic acidosis in a compensated phase at this temperature. The shift of the buffer bases was negative and amounted to $-2.8 \pm 0.5 \mathrm{mmol} / \mathrm{L}, \mathrm{pCO}_{2}-4.5 \pm 0.3$ $\mathrm{kPa}$. Due to the inclusion of the respiratory component of the compensation, the $\mathrm{pH}_{\text {ist. }}$ remained in the lower limit of the norm. These features can be explained by the fact that the temperature of $25{ }^{\circ} \mathrm{C}$ was below the required temperature regime recommended for chicken growing of this age $\left(29-31{ }^{\circ} \mathrm{C}\right)$. At $27{ }^{\circ} \mathrm{C}$ - the chickens of all studied ages had subcompensated respiratory alkalosis. At 31,33 , and $34{ }^{\circ} \mathrm{C}$, respiratory alkalosis passed into a decompensated phase, even among the chickens at the age of 20 days, with the accumulation of buffer bases above the norm. Knowledge of the nature of disorders and adaptive capabilities of the acid-base balance of blood among farm animals and poultry under heat stress in the practice of animal husbandry and poultry farming will allow to take timely measures to maintain health and high productivity.
\end{abstract}

Key words: acid-base balance, cattle, poultry, heat stress, productivity. 